\title{
PENDIDIKAN KEWIRAUSAHAAN MAHASISWA MELALUI INKUBASI DI UNIVERSITAS MUHAMMADIYAH MAGELANG
}

\author{
Agus Setiawan ${ }^{1 *}$, Oesman Raliby Al Manan², Tuessi Ari Purnomo ${ }^{2}$, Ardhin Primadewi ${ }^{1}$ \\ ${ }^{1}$ Program Studi Teknik Informatika, Fakultas Teknik, Universitas Muhammadiyah Magelang, Magelang, Indonesia \\ ${ }^{2}$ Program Studi Teknik Industri, Fakultas Teknik, Universitas Muhammadiyah Magelang, Magelang, Indonesia \\ *Penulis Korespondensi : setiawan@ummgl.ac.id
}

\begin{abstract}
Abstrak
Universitas Muhammadiyah Magelang (UMMgl) mempunyai visi "Unggul dalam Ilmu, Islami dalam Perilaku" yang dimana bertanggung jawab untuk memberikan bekal terhadap mahasiswanya untuk mandiri setelah lulus dari perguruan tinggi. Untuk menyiapkan itu maka UMMgl menekankan kepada seluruh mahasiswa untuk menjadi entrepreneur yang mandiri dan unggul, untuk menuju ke sana memang tidak mudah. Proses - proses dari kurikulum, magang, dan inkubator entrepreneur pun perlu disiapkan secara matang dan terstruktur. Menjadi wirausaha memang tidak mudah, membutuhkan mentor dan bimbingan yang tepat agar berhasil nantinya menumbuhkan jiwa kewirausahaan yang intinya adalah kemandirian pada jiwa mahasiswa UMMgl. Metode yang digunakan dalam pelaksanaan pendidikan kewirausahaan ini menggunakan metode Participatory Rural Appraisal yang melibatkan obyek menjadi subyek aktif kolaborasi. Tahapan yang dilakukan adalah 1) Rekruitmen, 2) Inkubasi, 3) Evaluasi. Hasil dari kegiatan ini didapatkan peningkatan dari 20 tenan menjadi wirausaha yang mempunyai produk untuk dikembangkan, dan 5 tenan mandiri siap mengembangkan produk bisnisnya, yaitu Bakso Bakar, Mr. Kriuk, Merchandise Online, Online Shop, dan Latte (coklat tempe).
\end{abstract}

Kata kunci: wirausaha, kewirausahaan, ummgl

\begin{abstract}
Universitas Muhammadiyah Magelang (UMMgl) has a vision of "Excellence in Science, Islam in Behavior" which is responsible for providing supplies to students to be independent after graduating from college. To prepare it, UMMgl emphasizes to all students to become independent and superior entrepreneurs, to get there is not easy. The processes of curriculum, internships, and entrepreneur incubators also need to be prepared carefully and structured. Being an entrepreneur is not easy, requires the right mentor and guidance so that it will succeed in fostering an entrepreneurial spirit which is essentially the independence of the soul of UMMgl students. The method used in the implementation of entrepreneurship education uses Participatory Rural Appraisal methods involving objects to be active subjects of collaboration. The steps taken are 1) Recruitment, 2) Incubation, 3) Evaluation. The results of this activity obtained an increase from 20 tenants to become entrepreneurs who have products to develop, and 5 independent entrepreneurs ready to develop their business products, namely Bakso Bakar, Mr. Kriuk, Merchandise Online, Online Shop, and Latte (chocolate tempe).
\end{abstract}

Keywords: enterpreneur, enterpreneurship, ummgl

\section{PENDAHULUAN}

Universitas Muhammadiyah Magelang mempunyai visi "Unggul dalam Ilmu, Islami dalam Perilaku” yang terus diterapkan untuk menjadikan mahasiswa yang unggul dan islami sesuai visi tersebut (UMMagelang, 2017). Universitas Muhammadiyah Magelang mempunyai kewajiban untuk membekali mahasiswa nantinya untuk menuju kemandirian dalam kehidupan setelah lulus nanti, sehingga Universitas Muhammadiyah Magelang menyiapkan dengan kurikulum untuk mendukung keilmuan di masing masing program studi dan juga memberikan keterampilan umum di bidang kewirausahaan untuk dapat mandiri dengan sesungguh - sungguhnya.
Kemudahan dalam memanfaatkan teknologi informasi sudah merupakan dukungan yang tidak terpisah dari layanan teknologi informasi seperti google.com (Setiawan \& Widaryanto, 2018). Sehingga UM Magelang dengan mudah melakukan pelacakan alumni, dan berdasarkan hasil treasure study yang dilakukan oleh beberapa program studi di Universitas Muhammadiyah Magelang ditemukan adanya saransaran alumni untuk meningkatkan kualitas dengan memberikan implementasi ilmu kewirausahaan yang lebih baik. Ditemukan juga persoalan ketidaksesuaian pekerjaan lulusan dengan bidang keilmuannya. Selain itu, berdasarkan hasil treasure study banyak alumni Universitas Muhammadiyah Magelang sebagian besar 
masih mendambakan bekerja sebagai PNS atau pegawai swasta daripada menjadi seorang wirausaha. Padahal peluang untuk menjadi PNS atau pegawai swasta sangat kecil bila dibandingkan jumlah lulusan perguruan tinggi tiap tahunnya, sehingga jumlah pengangguran lulusan perguruan tinggi masih menduduki tempat tertinggi dibanding lulusan pendidikan lainnya.

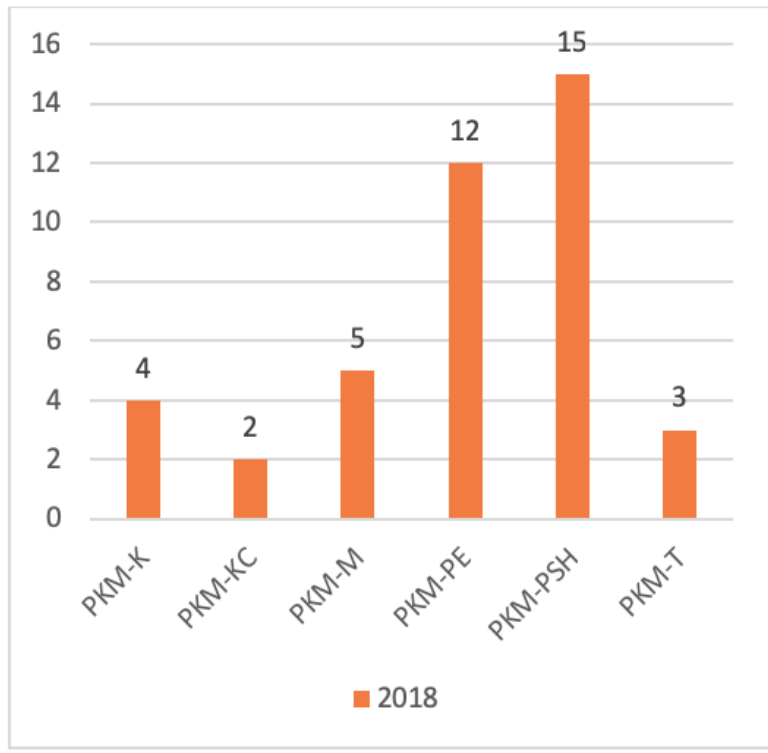

Gambar 1. Statistik PKM di UMMagelang pendanaan 2018 (Magelang, 2018)

Berdasarkan gambar 1 diatas mahasiswa UM Magelang diloloskan 41 PKM. Sehingga UM Magelang mampu bersaing secara nasional, dan mahasiswa UM Magelang mempunyai kreatifitas yang mampu bersaing secara nasional dibuktikan dengan lolosnya pendanaan PKM pada tahun 2018 ini. dan PKM Kewirausahaan didanai sejumlah 4 judul. Potensi judul yang lain tentu dapat dikembangkan sebagai produk kewirausahaan dari mahasiswa. Ini yang menjadikan para mahasiswa ini perlu diwadahi untuk didampingi dan difasilitasi untuk mewujudkan jiwa kewirausahaan pada mereka dan mampu menular kepada mahasiswa yang lain, sehingga dapat terwujud atmosfir kampus wirausaha.

Universitas Muhammadiyah Magelang telah mensosialisasikan spirit kewirausahaan pada hampir seluruh sivitas akademika mulai dari dosen, mahasiswa dan karyawan melalui pemberian mata kuliah wajib kewirausahaan pada setiap program studi yang ada,berbagai pelatihan dan workshop (UMMagelang, 2018) (Kemendikbud, 2014). Universitas Muhammadiyah Magelang mempunyai beberapa lembaga dan pusat untuk memacu lebih kencang di bidang kewirausahaan, dianataranya adalah Bank BMT LE Syariah untuk praktik bank syariah, PPUB sebagai pusat pengembangan usaha dan bisnis dari mahasiswa dan perguruan tinggi itu sendiri, KOMET merupakan komunitas mahasiswa entrepreneur yang dibentuk mahasiswa untuk berkumpul dan berdiskusi para mahasiswa entrepreneur, Unit Rawat Luka merupakan unit yang bertempat di Fakultas Ilmu Kesehatan yang mempunyai peran praktik pengembangan metode perawatan luka, adalah melakukan inkubasi untuk pengembangan wirausaha baru yang mandiri dan profesional.

Universitas Muhammadiyah Magelang mulai tahun 2016 sampai dengan sekarang 2018 mendapatkan hibah PPKIK yang tahun tersebut masih bernama IbIKK dengan judul IbIKK Pengembangan Usaha Bengkel Kampus "UMMagelang Autorized". PPKIK ini mempunyai salah satu tujuan yang mendukung dengan PPK ini yaitu untuk mempercepat pengembangan budaya kewirausahaan bagi mahasiswa untuk disiapkan menjadi technopreneur setelah lulus.

Tujuan dari kegiatan ini adalah untuk meningkatkan kompetensi kewirausahaan mahasiswa dan alumni di Universitas Muhammadiyah Magelang. Potensi besar mahasiswa untuk berwirausaha sesuai keilmuannya masih belum diolah dan manfaatkan sesuai kapasitas yang ada. Meskipun potensi yang dimiliki cukup memadai untuk pengembangan budaya kewirausahaan, namun sampai saat ini Universitas Muhammadiyah Magelang belum memiliki satu wadah yang berfungsi memberikan pendampingan, pembinaan, dan pelayanan tentang kegiatan kewirausahaan terutama bagi para mahasiswa. Kegiatan tersebut masih terbatas dilakukan oleh masing-masing fakultas yang mempunyai konsentrasi di bidang kewirausahaan.

\section{METODE}

Program Pengembangan Kewirausahaan (PPK) merupakan program yang melaksanakan pembinaan kepada tenant melalui pelatihan manajemen usaha dan sejumlah kegiatan kreatif lainnya untuk menghasilkan wirausaha baru yang mandiri berbasis iptek (Ristekdikti 2017). Program PPK setiap tahun direncanakan membina 20 calon wirausaha yang diutamakan adalah mahasiswa Program Kreativitas Mahasiswa Kewirausahaan dan Masyarat (PKMK) tahun 2016, 2017, 2018 sebanyak 15 orang dan mahasiswa yang sudah berwirausaha atau yang merintis usaha baru sebanyak 5 orang. Untuk memperoleh nama-nama mahasiswa yang pernah mengikuti PKM K yang didanai oleh Dirjen Belmawa, pelaksana program PPK bekerjasama dengan Biro Akademidk dan Kemahasiswaan, Lembaga Pengembangan Mahasiswa dan Alumni, Pusat Pengembangan Usaha dan Bisnis.

Metode yang akan digunakan untuk pelaksanaan kegiatan pengabdian pada masyarakat ini adalah metode pemberdayaan masyarakat partisipatif dengan model Participatory Rural Apraissal, yaitu suatu metode pendekatan dalam proses pemberdayaan dan peningkatan partisipasi masyarakat, yang penekanannya pada keterlibatan masyarakat dalam keseluruhan kegiatan yang dilaksanakan (Febriyanto, 2015) (Novialumi, 2017). Pelaksanaannya dengan menggunakan metode ini melibatkan segala hal kegiatan dengan partisipasi masyarakat. Sehingga tidak 
lagi masyarakat dipandang hanya sebagai obyek, namun sudah berubah menjadi subyek. Metode ini diharapkan mampu meningkatkan partisipasi tenan sehingga mereka mempunyai kemauan keras juga untuk berpartisipasi tanpa dipaksa. Masyarakat yang dimaksud dalam hal ini adalah kelompok wirausaha mahasiswa dan alumni di UMM.

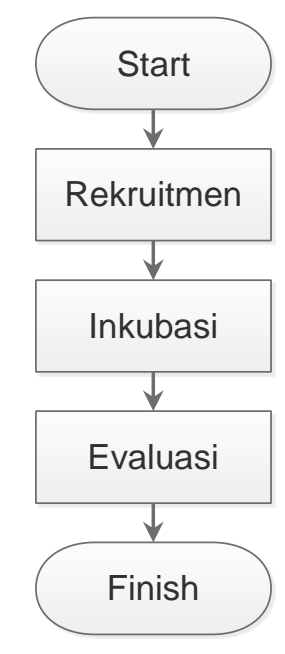

Gambar 2. Alur Pelaksanaan Kegiatan

Gambar 2 diatas menunjukkan tahapan - tahapan yang akan dilakukan untuk pendidikan kewirausahaan di Universitas Muhammadiyah Magelang.

\section{A. Rekruitmen}

Rekruitmen dilakukan melalui tahapan yang sesuai dengan aturan yang diatur bersama dengan beberapa biro dan lembaga di Universitas Muhammadiyah Magelang. Rekruitmen ini dilakukan untuk mendapatkan atau menjaring mahasiswa yang memang siap dan mampu aktif mengikuti program pendidikan kewirausahaan.

\section{B. Inkubasi}

\section{1) Inclass Training}

Pelatihan dilaksanakan untuk memberikan pengetahuan kewirausahaan, mendorong tumbuhnya obsesi dan motivasi berwirausaha, meningkatkan pemahaman manajemen (organisasi, produksi, keuangan dan pemasaran), merubah pola pikir (mindset) tentang kewirausahaan dan membuat rencana bisnis atau studi kelayakan usaha.

\section{2) Outclass Training}

Peserta PPK setelah melaksanakan magang kewirausahan juga melakukan studi lapangan (studi banding), ke beberapa industri yang sangat prospektif. Studi lapangan dilakukan selama 1 hari penuh yang didampingi oleh dosen pembimbing lapangan dan pengusaha mitra. Materi studi lapangan disampaikan langsung oleh pimpinan perusahaan meliputi; manajemen produksi, manajemen sumberdaya manusia, manajemen keuangan, manajemen pemasaran, prospek pengembangan usaha dan tantangannya. Studi banding dilaksanakan untuk memperkaya wawasan, mengembangkan kreativitas, dan mempertajam analisis usaha.

\section{3) Pendampingan}

Pembimbingan kepada tenant dilakukan sejak pelatihan, magang di industri mitra, studi banding, lokakarya, penyusunan rencana bisnis sampai pada realisasi bisnis. Dengan banyak berinteraksi dan berkomunikasi antara tenant dengan pembimbing diharapkan terjadi sinergis hubungan antara pembimbing dan tenant. Pola pengawaswan terhadap tenant dilakukan dengan cara memonitoring dan mengevaluasi aktivitas yang dilakukan tenant selama mengikuti program PPK mulai dari kegiatan pelatihan sampai dengan akhir kegiatan PPK.

4) Magang

Magang dilakukan dengan cara menempatkan tenant pada perusahaan/UKM Mitra terpilih yang mapan dan mampu memfasilitasi mahasiswa berwirausaha. Kegiatan magang pada perusahaan dilaksanakan untuk memberikan pengalaman praktis kewirausahaan kepada tenant dengan cara ikut bekerja sehari-hari pada perusahaan tersebut. Pemilihan tempat magang pada Industri/UKM Mitra disesuaikan dengan jenis usaha yang dilakukan/diminati oleh tenant sehingga terjadi sinergisme antara UKM Mitra dengan tenant berdasarkan jenis usaha yang sudah/akan dikembangkan.

\section{5) Bantuan Biaya}

Pada tahun pertama, dari 20 (dua puluh) orang tenant peserta program PPK minimal diharapkan 5 oran tenant menjadi wirausaha baru dan mampu mengembangkan kegiatan wirausaha bagi tenant yang telah memulai berwirausaha. Bagi 5 orang tenant yang rencana bisnisnya terpilih untuk direalisasikan akan diberi bantuan berupa fasilitas/supporting misalnya: peralatan, lokasi usaha di area kampus, kemudahan penggunaan berbagai fasilitas kampus sebagai stimulus usahanya/start up business.

\section{Evaluasi}

Evaluasi ini dilakukan untuk mengetahui seberapa berhasil implementasi inkubasi dilakukan dalam rangka pendidikan kewirausahaan di Universitas 
Muhammadiyah Magelang. Evaluasi tetap melibatkan para tenan untuk saling mendapatkan koreksi dari tim pelaksana dan tenan sebagai penerima manfaat.

\section{HASIL DAN PEMBAHASAN}

Berdasarkan pelaksanaan kegiatan yang sudah dilakukan, didapatkan hasil sebagai berikut:

A. Rekruitmen

Rekrutimen mahasiswa diikuti oleh 30 mahasiswa yang mendaftar dan lolos administrasi dengan ketentuan sebagai berikut:

1) Mahasiswa yang telah mengikuti PKM K dan PKM M (Program Kreativitas Mahasiswa Kewirausahaan dan Masyarakat) atau kegiatan Kewirausahaan sejenis.

2) Mahasiswa yang mempunyai minat dan bakat kewirausahaan, diutamakan mahasiswa yang telah atau sedang merintis usaha baru sebagai wirausaha

3) Berstatus sebagai mahasiswa aktif pada semester berjalan ditunjukkan dengan Kartu Tanda Mahasiswa (KTM) pada semester yang bersangkutan

4) Telah menyelesaikan kuliah 3 (tiga) semester dan duduk di semester 4 (empat) ke atas

5) Memiliki Indeks Prestasi Kumulatif (IPK) minimum 2.5 ditunjukkan dengan Kartu Hasil Studi (KHS)

6) Aktif dalam kegiatan kemahasiswaan terutama pada kegiatan Himpunan Mahasiswa Jurusan (HMJ)

7) Memiliki obsesi untuk mendirikan kegiatan kewirausahaan dengan latar belakang keluarga sedapat mungkin yang memiliki kegiatan wirausaha

Karena kegiatan ini adalah kegiatan pertama kali di Universitas Muhammadiyah Magelang, maka banyak mahasiswa yang masih belum mengetahui secara jelas apa itu PPK, walaupun kami sudah melakukan sosialisasi terhadap mahasiswa. Mahasiswa banyak mengalami kendala pada saat wawancara, karena seleksi ini meliputi wawancara ditujukan untuk mengetahui lebih mendalam mengenai: Latar belakang keluarga yang berkecimpung di bidang kewirausahaan, Obsesi dan motivasi calon tenant untuk menjadi Wirausaha Baru, Kemampuan dan potensi kewirausahaan yang ada pada calon tenant, Softskill/kepribadian calon tenant secara keseluruhan, mahasiswa gagal pada saat mendefinisikan apa yang menjadi landasan mereka berwirausaha. Walaupun poin wawancara rendah namun kami dapat mengukur keseriusan para calon tenan dengan para tenan menjelaskan apa yang akan mereka lakukan saat menjadi tenan dalam kegiatan ini.

\section{B. Inkubasi}

\section{1) Inclass Training}

Pelatihan ini dilakukan dengan mengundang praktisi dan mendatangi praktisi kewirausahaan. Narasumber menyampaikan kajian - kajian dalam pendidikan kewirausahaan yang meliputi:

- Pandangan Kewirausahaan

- Proser Berwirausaha dan Merubah Cara Pandang dalam berwirausaha

- Kreatifitas dan Ide Bisnis

- Membuat dan Memulai Bisnis

- Konsep Kualitas

- Konsep Strategi dan Manajemen

- Konsep Operasional

- Konsep Pemasaran

- Kemampuan Penjualan

Inclass training ini secara aktif diikuti oleh para tenan. Hasil dari kegiatan ini $80 \%$ tenan mengikuti secara aktif yaitu ditunjukkan dengan kehadiran para tenan pada tiap sesi.

\section{2) Outclass Training}

Pendidikan di luar kelas dilakukan dibeberapa tempat UKM di Magelang dan Sekitarnya. Kunjungan ke Rumah Kreatif BUMN (RKB) Solo menjadi sasaran untuk menimba ilmu sebagai incubator wirausaha terbaik di Indonesia. Para tenan menadapatkan pemaparan langsung dari para praktisi disana dan melihat fasilitas yang banyak dan mendukung kegiatan bisnis online $\mathrm{di}$ RKB Solo. Sehingga dengan adanya kegiatan outclass ini mampu meningkatkan cara pandang tenan bahwa di luar sana banyak orang yang berwirausaha juga. Antusiasme partisipasi dari tenan $100 \%$ mengikuti kegiatan ini, sehingga metode PRA ini mampu memberikan dampak secara langsung kegiatan yang dilakukan dan direncanakan bersama dapat di implementasikan dengan bersama-sama pula. Tenan mendapatkan tips dan trik menjadi seorang wirausaha langsung dari para pelaku yang sudah level nasional. Sehingga para tenan tergugah dengan

\section{3) Pendampingan}

Tim dari PPK di Universitas Muhammadiyah Magelang melakukan pendampingan secara intensif di ruang PPK selama jam kerja, senin sampai dengan sabtu. Mahasiswa bebas datang atau berkomunikasi dengan media social dengan para tim PPK. Pendampingan ini 
menghasilkan interaksi yang positif dengan mahasiswa karena pendampingan ini masuk dalam penilaian yang nantinya akan di akumulasi di akhir pada tahapan bantuan biaya. Pada awal kegiatan tenan yang belum pernah merintis usaha mengalami kendala mengenali potensi dirinya. Sehingga mereka kesulitan untuk menentukan arah bisnis apa yang akan mereka kembangkan. Dari beberapa tenan sudah ada juga yang cukup matang karena di mulai dengan program PKM K Belmawa Ristekditi, sehingga sudah menekuni bidang tertentu tinggal mengembangkan saja. Tenan yang aktif dan dapat mengimplementasikan kewirausahaan dengan nyata tentu akan mendapatkan nilai tertinggi. Tenan yang tertinggi nilainya pada tahapan ini adalah pada produk Mr. Kriuk yang terus mengembangkan produknya dan aktif mengikuti kegiatan pameran. Pameran dilakukan selama 2 kali yaitu pada event puasa yaitu berjualan di pinggir jalan untuk menyediakan makanan berbuka puasa, dan event saat milad Universitas Muhammadiyah Magelang.

\section{4) Magang}

Magang bagi para tenan dibagi menjadi beberapa kelompok. Kelompok ini didasarkan pada jenis produknya. Pada tahun 2018 ini ada penempatan magang pada 10 tempat magang, diantaranya adalah RM Brambang Salam, Nur Cake, Bengkel Unimma Autocare, Pusat Pembuatan Mainan Anak, Software House, Café Coffee, Klinik Hewan, Kerajian Rajut Borobudur, Peternakan Ayam, dan Surya Mart. Semua bidang yang ada dari sejumlah 20 tenan ini mendapatkan tempat magang semua. Mereka mendapatkan dosen pendamping lapangan dan pembimbing lapangan dari industry yang akan mendampingi selama 5 minggu magang. Mereka memperlajari dari proses awal produksi sampai dengan pemasaran produk, hingga manajemen dalam industry tersebut. Dari hasil pelaksanaan para mahasiswa dan tempat magang (Indsutri) merasa saling diuntungkan karena ada interaksi yang mahasiswa selaku tenan dapat memberikan masukan sesuai dengan bidang ilmu yang diperoleh dibangku kuliah dalam bentuk teori, dan pelaku industri memberikan pelajaran langsung kepada para mahasiswa dalam bentuk empiris. Sehingga magang ini meberikan kemantapan dalam jiwa mahasiswa untuk lebih tekun mengembangkan jiwa kewirausahaannya.

\section{5) Bantuan Biaya}

Pada awal diterima mejadi tenan, mereka 20 tenan langsung mendapatkan bantuan biaya awal yang sama untuk mengembangkan dan memafaatkan biaya tersebut untuk riset pembukaan bisnis baru atau mengembangkan bisnis baru. Bantuan biaya memberikan dampak yang signifikan karena tenan tidak perlu takut mengembalikan bantuan biaya awal ini jika mengalami kegagalan. Bantuan biaya dilanjutkkan dengan terpilihnya lima terbaik tenan mendapatkan bantuan pinjaman modal tanpa tambahan biaya apapun selama satu tahun, yaitu Catur dengan bakso bakarnya, Miftah dan Rahma dengan Mr. Kriuknya, Septi dengan Dagangan Tas Online-nya, Tri Wulandari dan Fitriyah dengan Coklat Tempe (latte) nya, dan Dimas dengan Handy Craft-nya. Bantuan biaya ini untuk mengembangkan bisnis dari lima terbaik tenan itu yang akan meluaskan pasar di masyarakat luas.

\section{Evaluasi}

Evaluasi kegiatan dilakukan bersama karena sesuai dengan model PRA ini. Tim pelaksana PPK dan Tenan bersama-sama mengevaluasi kegiatan yang telah direncakan bersama. Hasil evaluasi ini akan digunakan sebagai peningkatan pendidikan kewirausahaan di tahun berikutnya. Evaluasi dibagi menjadi 2 bidang, yaitu evaluasi rekruitmen dan inkubasi.

Evaluasi rekruitmen terjadi pada proses pengumuman yang terlalu singkat. Poster yang ada kurang begitu menarik calon tenan karena masih pertama kali pendidikan kewirausahaan ini dilakukan. Sehingga maish belum ada ukiran prestasi yang membuat calon tenan menambah ketertarikan. Sehingga perbaikan kedepan adalah definisi PPK di Universitas Muhammadiyah Magelang lebih disosialisasikan bersama dengan fakultas dan program studi kepada para mahasiswanya.

Evaluasi Inkubasi ini pada ruang yang masih cukup kecil yang masih menjadi satu dengan administrasi, sehingga kedepannya diusulkan ruang inkubasi kewirausahaan untuk menambah kenyamanan saat konsultasi dan pameran produk dari para tenan. Ruang ini perlu juga untuk inclass training yang agar tidak pindah - pindah karena gentian dengan ruang kelas. Tentu ini tidak mudah namun rencana sebagai incubator wirausaha yang mandiri menjadi visi dari PPK di Universitas Muhammadiyah Magelang ini. 
Tabel 1. Daftar Tenan dan Bidang Usahanya

\begin{tabular}{|c|c|c|}
\hline No & Produk & Mahasiswa \\
\hline 1 & Bolu Kurawa & $\begin{array}{l}\text { Fera } \\
\text { Wihelminah, } \\
\text { Atifa }\end{array}$ \\
\hline 2 & Mr. Kriuk & $\begin{array}{l}\text { Mftahwati } \\
\text { Editia, Fauziah } \\
\text { Rahmawati }\end{array}$ \\
\hline 3 & Cappucino Cincau & Suseno \\
\hline 4 & Online shop TAS & Fiani Verawati \\
\hline 5 & Rajutan & $\begin{array}{l}\text { Eva } \\
\text { Pramugiarti }\end{array}$ \\
\hline 6 & Kantin Kejujuran & Yuliani \\
\hline 7 & Online shop TAS & $\begin{array}{l}\text { Septi } \\
\text { Wulandari }\end{array}$ \\
\hline 8 & $\begin{array}{l}\text { Angkringan \&Telur } \\
\text { Gulung }\end{array}$ & $\begin{array}{l}\text { Atina Hana } \\
\text { Maulida } \\
\text { Domi }\end{array}$ \\
\hline & Thai Tea dan Tahu & Rahardian \\
\hline 10 & $\begin{array}{l}\text { Walik Aci } \\
\text { Bispak Sayur untuk } \\
\text { Kucing }\end{array}$ & $\begin{array}{l}\text { Lusifah Nurul } \\
\text { Huda }\end{array}$ \\
\hline 11 & Online shop Fashion & $\begin{array}{l}\text { Maylin } \\
\text { Thamara } \\
\text { Deviantami }\end{array}$ \\
\hline 12 & $\begin{array}{l}\text { Online Handycraft Bros } \\
\text { dan Pernak Pernik }\end{array}$ & $\begin{array}{l}\text { Dhuca } \\
\text { Isnaningsih }\end{array}$ \\
\hline 13 & Bakso Bakar & Catur \\
\hline 14 & Merchendise Online & $\begin{array}{l}\text { Dimas } \\
\text { Nugroho }\end{array}$ \\
\hline 15 & Koki Bisteak & $\begin{array}{l}\text { Amirotul } \\
\text { Chakimah dan } \\
\text { Ernawati }\end{array}$ \\
\hline 16 & Pitik Shop & Ahmad Faisal \\
\hline 17 & Bengkel Sepeda Motor & Rio Riskiyanto \\
\hline 18 & Latte (Coklat Tempe) & $\begin{array}{l}\text { Tri Wulandari, } \\
\text { Fitriyah }\end{array}$ \\
\hline
\end{tabular}

Berdasarkan hasil pendidikan kewirausahaan ini, seluruh tenan yang mengikuti sudah menemukan arah wirausaha dengan mengembangkan produk masing masing yang dapat dilihat pada table 1. Delapan belas produk dikembangkan oleh para tenan dengan proses yang panjang. Tenan mengembangkan produk usahanya melalui tahapan dari proses inclass training sampai dengan pendampingan dan mendapatkan pembiayaan.

\section{KESIMPULAN}

Berdasarkan pelaksanaan kegiatan pendidikan kewirausahaan dalam program PPK di Universitas Muhammadiyah Magelang melalui inkubasi selama tahun 2018 ini, dari kegiatan inkubasi pada tahapan pendampingan disimpulkan sebagian besar tenan memang belum mampu mengidentifikasi potensi yang ada pada dirinya. Ini ditunjukkan saat pendampingan awal para tenan kesulitan mencari tahu apa kekurangan dan kelebihan dari para tenan itu sendiri. Seluruh tahapan inkubasi ini mampu memberikan peningkatan dan pencerahan dengan ditunjukkan mahasiswa sudah memilih arah untuk memulai bisnis apa sesuai dengan table 1. Para tenan berhasil menginisiasi usaha untuk dikembangkan menjadi suatu kegiatan usaha produktif. Dari kegiatan ini juga dihasilkan tenan sejumlah 5 produk yang diunggulkan mampu bersaing dan telah dipasarkan secara luas di masyarakat, yaitu Catur dengan bakso bakarnya, Miftah dan Rahma dengan Mr. Kriuknya, Septi dengan Dagangan Tas Online-nya, Tri Wulandari dan Fitriyah dengan Coklat Tempe (latte) nya, dan Dimas dengan Merchandise Online-nya. Dan lima tenan ini juga diapresiasi dengan diberikannya bantuan biaya modal tanpa biaya tambahan dengan jangka waktu setahun untuk mengembangkan usahanya lebih produktif lagi dan benar - benar mandiri.

Diharapkan kegiatan-kegiatan yang telah dilakukan tersebut dapat berkelanjutan dan tenan dapat menjadi wirausahawan/wati mandiri. Oleh karena itu, dukungan dari berbagai pihak sangat dibutuhkan.

\section{UCAPAN TERIMAKASIH}

Terima kasih disampaikan kepada DRPM Ristekdikti dan LP3M UM Magelang yang telah memberikan dukungan moril maupun materiil untuk penyelesaian program pengembangan kewirausahaan yang akhirnya dapat dijadikan artikel pada jurnal ini.

\section{DAFTAR PUSTAKA}

Febriyanto. (2015). Strategi Peningkatan Kewirausahaan Bagi Mahasiswa Di Pendidikan Tinggi. Jurnal Bisnis Darmajaya, 01 (01), 105115.

Kemendikbud. Peraturan Menteri Pendidikan Dan Kebudayaan No. 49 Tahun 2014 Tentang Standar Nasional Pendidikan Tinggi (2014). Indonesia.

Magelang, U. M. (2018). Sambutan Dan Laporan Rektor Ummagelang Milad Ke-54 Th. 20181. Magelang.

Novialumi, A. (2017). Strategi Perguruan Tinggi Dalam Meningkatkan Jiwa Kewirausahaan Pada Mahasiswa Stmik Mitra Karya Bekasi. Jurnal Parameter, 2(1).

Setiawan, A., \& Widaryanto, R. (2018). Mobile Crm Student-Parent Information System. Iop Conference Series: Materials Science And Engineering, $\quad 403, \quad 012076$. Https://Doi.Org/10.1088/1757899x/403/1/012076

Ummagelang. (2017). Rencana Jangka Panjang Universitas Muhammadiyah Magelang 20082024. Magelang.

Ummagelang. (2018). Kurikulum Berbasis Kompetensi Dan Kkni Program Studi Universitas Muhammadiyah Magelang. Magelang: Ummagelang. 
Dokumentasi Kegiatan

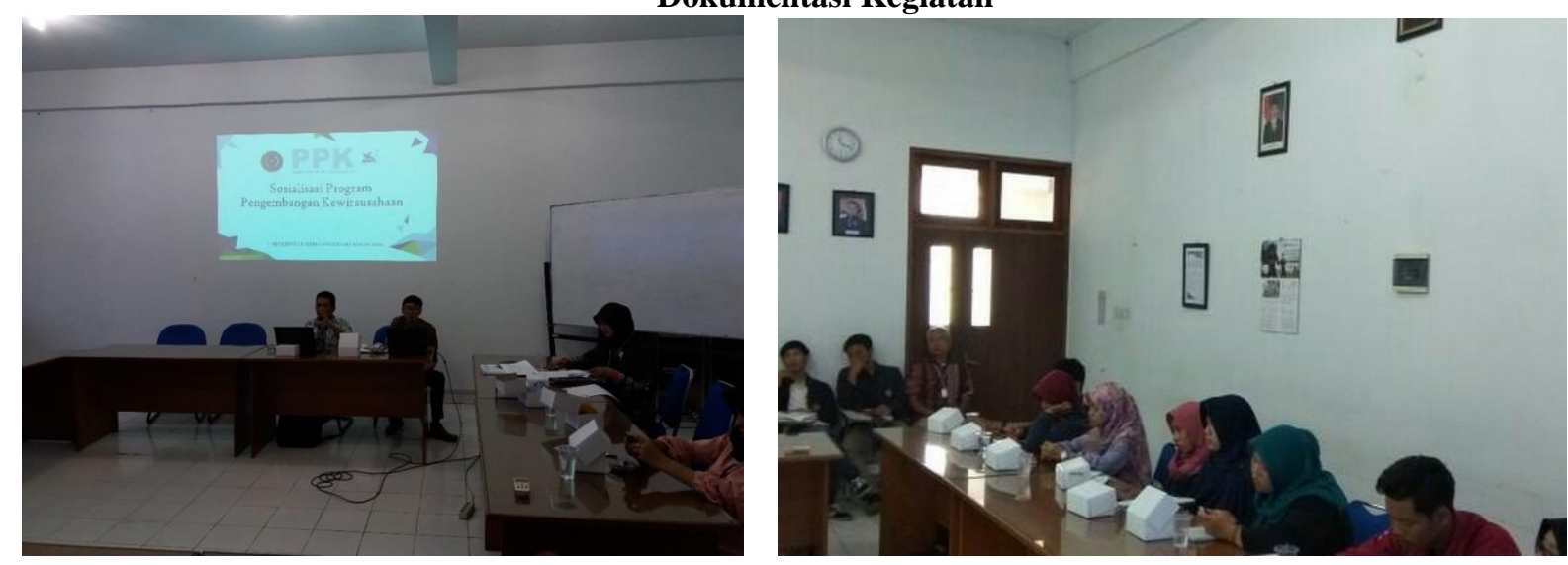

Sosialisasi PPK dan Rekruitmen
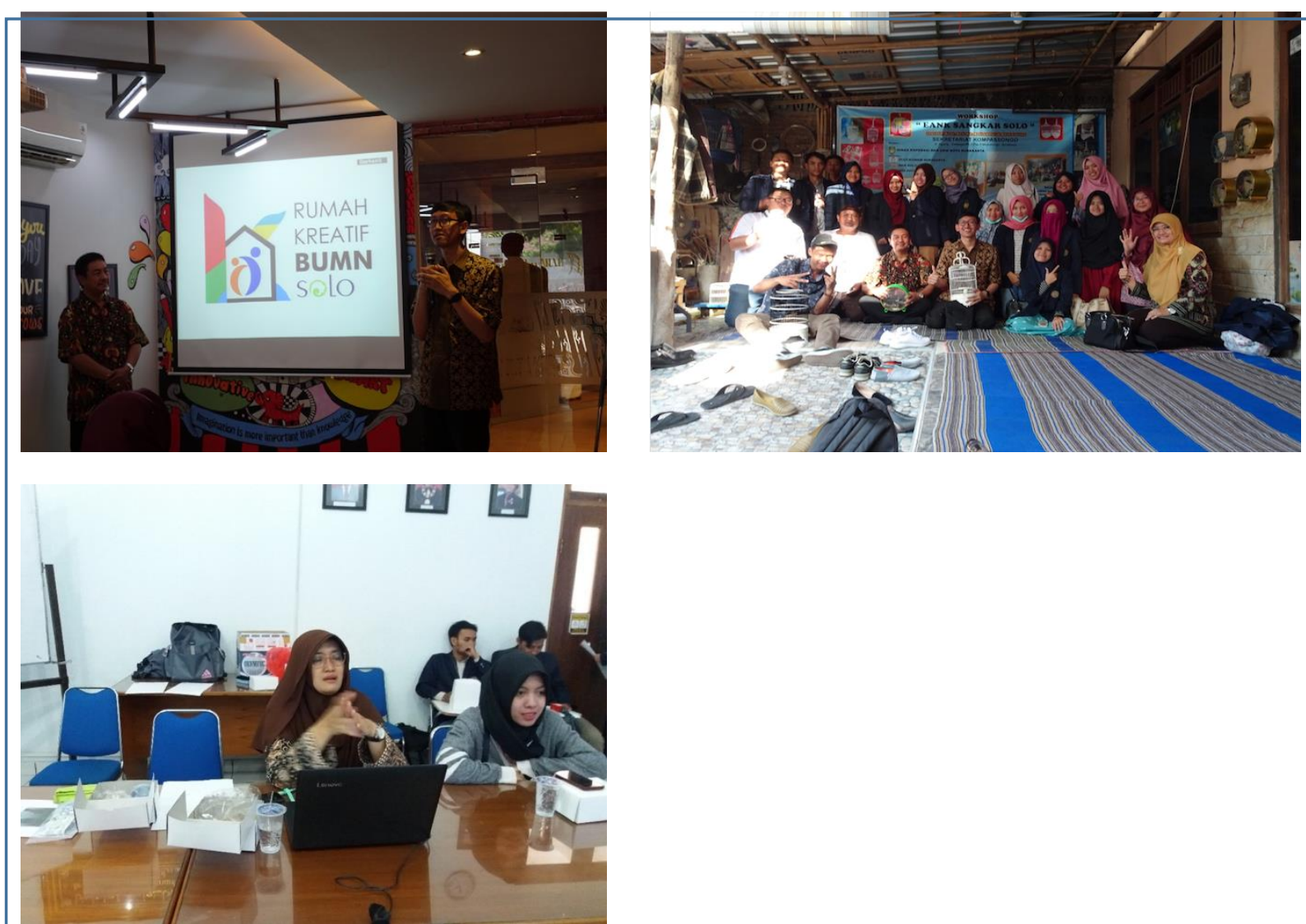

Inkubasi PPK 


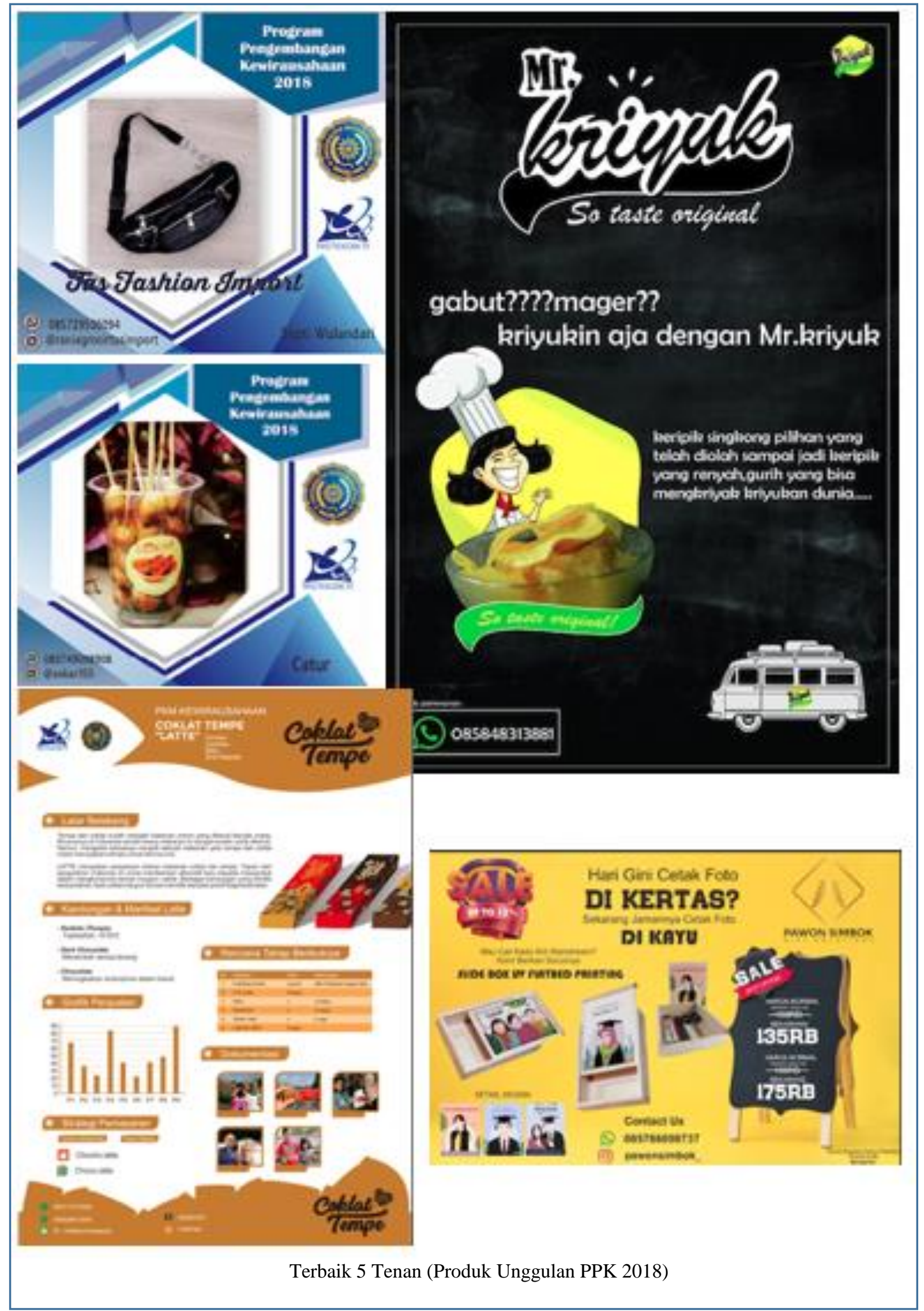

